\title{
Contents, Volume 11 (2000)
}

Clayhills,T.: On the occurrence of the genus Hyperaspis (Col. Coccinellidae) in Fenno-Scandian countries ... 109-112

Dubatolov, V. V. \& Kosterin, O. E.: Nemoral species of Lepidoptera (Insecta) in Siberia: a novel view on their history and the timing of their range disjunctions

141-166

Gourov, A.V.: Hylobius species (Coleoptera: Curculionidae) from Siberia and the distribution patterns of adults feeding in Scots pine stands ..................57-66

Gupta, S., Gupta, A. \& Meyer-Rochow, V. B.: Post-embryonic development of the lateral eye of Cloeon sp. (Ephemeroptera: Baetidae) as revealed by scanning electron microscopy .... 89-96

Haitlinger, R. 2000: Mites (Acari: Prostigmata: Erythraeidae, Trombidiidae) new to the fauna of Norway, Finland, Russia, Latvia and Lithuania, with a description of Podothrombium roari n. sp. ........... 187-193

Kozlov, M. V., Jalava, J. \& Shutova, E.: New Records of Lepidoptera from the Kola Peninsula, Northwestern Russia $131-136$

Koponen, M.: Five alysiine species new to Finland (Hymenoptera: Braconidae; Alysiinae) ........... 239-243.

Krivosheina, N. P.: A new and little known species of the genus Aspistes Meig. (Diptera, Scatopsidae) from Finland

119-123

Laasonen, E. \& Laasonen, L.: Habitual differences of Phyllonorycter salictella (Zeller, 1846) and $P$. heringiella (Grönlien, 1932) (Lepidoptera: Gracillaridae) in two Finnish materials; a problem pair

$175-181$

Lindskog, P. \& Viklund, B.: On Deraeocoris lutescens (Schilling) and Pinalitus atomarius (Meyer-Dür) in Sweden (Heteroptera: Miridae) ................. 231-238

Logunov, D.V. \& Koponen, S.: A synopsis of the jumping spider fauna in the Russian Far East (Araneae, Salticidae)

$67-87$

Marttila, O., Saarinen, K. \& Marttila, P: Six years from passing bell to recovery: Habitat restoration of the threatened Chequered Blue Butterfly (Scolitantides orion) in SE Finland 113-117

van Nunen, M., Itämies, J. \& Ahola, M: The larval description of Tinea steueri Petersen, 1966 and Tinea svenssoni Opheim, 1965 (Lepidoptera, Tineidae..... 97-108

Nupponen, K., Bengtsson, B. Å. , Kaitila, J-P., Nupponen, T., Junnilainen, J. \& Olschwang, V.: The scythridid fauna of the southern Ural Mountains, with description of fourteen new species (Lepidoptera: Scythrididae). $5-34$

Papp, J.: Bracon polaris Hellén, redescription of a little known species (Hymenoptera, Braconidae)
Wahlberg, N.: Comparative descriptions of the immature stages and ecology of five Finnish melitaeine butterfly species (Lepidoptera: Nymphalidae) ... 167-174

Vikberg, V. V.: A re-evaluation of five European species of Spilomena with a key to European species and relevance to the fauna of North Europe, especially Finland (Hymenoptera: Pemphredonidae) ..... 35-55

Vikberg, V. \& Koponen, M.: On the taxonomy of Seleucus Holmgren and the European species of Phrudinae (Hymenoptera: Ichneumonidae) ......... 195-228

\section{Brief Reports}

Jansson, A. 2000: Interesting collection of Corixidae (Heteroptera) from a fish pond ......................... 183-184

Jussila, R.: Dyspetes praerogator (Thomson, 1883), a new species and genus to Finland and Denmark (Hym., Ichneumonidae, Tryphoninae ................................ 88

Jussila, R.: Netelia arabs (Strand) new to Israel and $N$. caucasica (Kokujev) new to Sweden (Hymenoptera: Ichneumonidae; Tryphoninae) ............................ 140

Mannerkoski, I.:Ceutorhynchus larvatus Schultze and Ceutorhynchus pallidicornis Gougelet \& Brisout de Barneville: On Pulmonaria obscura living weevils in Finland (Coleoptera: Curculionidae) .......... 245-247

Mannerkoski, I.: Clambus nigrellus Reitter (Coleoptera: Clambidae), an overlooked beetle species in Finland 229-230

\section{Short Reports}

Haarto, A.: Scenopinus vitripennis Meigen (Dipetra: Scenopinidae), Platycheirus nigrofemoratus Kanervo and Cheilosia sootryeni Nielsen (Diptera: Syrphidae), Amobia signata (Meigen) (Diptera: Sarcophagidae) and Chaetostevnia brevicornis (Zetterstedt) (Dipetra: Rhinophoridae) new to Finland...

Muona, J: Lyctus africanus Lesne (Coleoptera: Bostrichidae) and Stromatium fulvum (Villers) (Coleoptera: Cerambycidae) new to Finland ................................. 2

Silfverberg, H.: Otiorhyncellus corruptor (Hast) (Coleoptera: Curculionidae) new to Finland ..................... 2

Laasonen, E.M. \& Laasonen, L.: Oxyethira boreella Svensson \& Tjeder, 1975 (Trichoptera: Hydroptilidae) new to Finland

Haarto, A.: New provincial records of Beris fuscipes Meigen, B. strobli Dusek \& Rozkosny), Odontomyia argentata (Fabricius) (Diptera:Stratiomyidae), Renocera pallida (Fallén), Antichaeta atriseta (Loew) (Diptera: Sciomyzidae), Metobia argyrocephala (Meigen), Helicophagella crassimargo (Pandellé), Pierretia sexpunctata (Fabricius), Parasarcophaga caerulescens (Zetterstedt) (Diptera:Sarcophagidae), Bellardia stric- 
ta (Villeneuve), Calliphora subalpina (Ringdahl), Pollenia labialis Robineau-Desvoidy (Diptera: Calliphoridae) and Siphona setosa Mesnil (Diptera: Tachinidae) 2-4

Laasonen, E.M. \& Laasonen, L.: New provincial records of Oxyethira falcata Norton, 1893 (Trichoptera: Hydroptilidae), Apatania dalecarlica (Forslund, 1942) and Limnephilus externus Hagen, 1861 (Trichoptera, Limnephilidae)

Lagercrantz, C-G.: Faunistic rarities of the Lepidoptera Oligia fasciuncula (Haw.) and Nycteola asiatica (Krul.) (Noctuidae

Silfverberg, H.: Ceutorhyncellus cakilis (Hansen) (Coleoptera: Curculionidae) new to Estonia

\section{Reviews}

Boucias, D.G. \& J.C. Pendland 1998: Principles of Insect Pathology. Kluwer Academic Publishers, Boston/Dordrecht/London. Pp. 537 (V.B. Meyer-Rochow)......

Chadwick, D. J. (organizer) \& Goode, J. A. (Eds.) 1999: Insect-plant Interactions and Induced Plant Defence (Novartis Foundation Symposium 223). John Wiley \& Sons Ltd, Chichester, England. 281 pp. (V.B. Meyer-Rochow) 185-186

Crane, E. 1999: The World History of Beekeeping and Honey Hunting. 682 pp. Nearly 500 illustrations. Gerald Duckworth \& Co. Ltd. London. ISBN 07156
2827 5. Price $£ 85$ (Antti Pekkarinen \& Anna-Liisa Varis) ............................................................. 194 Ebert, G. (ed.) 1997, 1997 \& 1998: Die Schmetterlinge Baden-Württembergs. Bände 5-7. Sesiidae, Arctiidae, Noctuidae. $575+622+582$ pp., $400+512+483$ colour photographs, $360+433+329$ diagrams and drawings, and $133+187+170$ distribution maps (Kauri Mikkola) .56

Hansen, M. 1999: Hydrophiloidea (Coleoptera). World Catalogue of Insects. 2. - Apollo Books $416 \mathrm{pp}$. ISBN 87-88757-31-5. Price DKR 690:- (standing order discount $10 \%$ available from publisher Apollo Books, Kirkeby Sand 19, DK-5771 Stenstrup) (Olof Biström) 118

Walker, J.B., Keirans, J.E. \& Horak, I.G. 2000: The genus Rhipicephalus (Acari, Ixodidae). A Guide to the Brown Ticks of the World. Cambridge University Press, xii +643 pp. ISBN 052148008 6. Price $£ 70$ (US\$105) (Seppo Koponen \& Ritva Niemi) .... 124

\section{Announcements}

Symposium: Biodiversity of insects and spiders on the islands of the central part of the Baltic Sea 244

INDEX to genera and species, Volume 11 (2000) 249-260

CONTENTS, Volume 11 (2000) 261-262 